Original Article

\title{
Impact of nitrogen and phosphorus fertilizers on Cry1Ac protein contents in transgenic cotton
}

\author{
Impacto de fertilizantes de nitrogênio e fósforo nos conteúdos de proteína Cry 1 Ac em \\ algodão transgênico
}

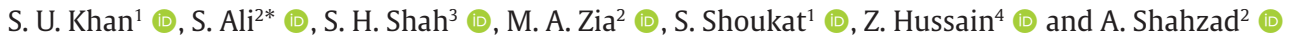 \\ ${ }^{1}$ PARC Institute of Advanced Studies in Agriculture - PIASA, National Agricultural Research Centre - NARC, Islamabad, Pakistan \\ ${ }^{2}$ National Institute for Genomics \& Advanced Biotechnology - NIGAB, National Agricultural Research Centre - NARC, Islamabad, Pakistan \\ ${ }^{3}$ Department of Agricultural Sciences, Faculty of Sciences, Allama Iqbal Open University, Islamabad, Pakistan \\ ${ }^{4}$ Centre for Biotechnology and Microbiology, University of Swat, Swat, Khyber Pukhtunkhwa, Pakistan
}

\begin{abstract}
Application of different fertilizers to check the efficiency of expression of Bt (Bacillus thuringiensis) gene in one of the leading commercialized crops (cotton) against Lepidopteran species is of great concern. The expression of Cry protein level can be controlled by the improvement of nutrients levels. Therefore, the myth of response of Cry toxin to different combinations of NP fertilizers was explored in three Bt cotton cultivars. Combinations include three levels of nitrogen and three levels of phosphorus fertilizers. Immunostrips and Cry gene(s) specific primer based PCR (Polymerase Chain Reaction) analysis were used for the presence of $B t$ gene that unveiled the presence of Cry1Ac gene only. Further, the ELISA (enzyme-linked immunosorbent assay) kit was used to quantify the expression of Cry1Ac protein. Under various NP fertilizers rates, the level of toxin protein exhibited highly significant differences. The highest toxin level mean was found to be 2.3740 and $2.1732 \mu \mathrm{g} / \mathrm{g}$ under the treatment of $\mathrm{N}_{150} \mathrm{P}_{75} \mathrm{~kg} \mathrm{ha}^{-1}$ combination while the lowest toxin level mean was found to be 0.9158 and $0.7641 \mu \mathrm{g} / \mathrm{g}$ at the $\mathrm{N}_{50} \mathrm{P}_{25}$ $\mathrm{kg} \mathrm{ha}^{-1}$ level at 80 and 120 DAS (Days After Sowing), respectively. It was concluded from the research that the usage of NP fertilizers has a positive relation with the expression of Cry $1 \mathrm{Ac}$ toxin in Bt cotton. We recommend using the $\mathrm{N}_{150} \mathrm{P}_{50} \mathrm{~kg} \mathrm{ha}^{-1}$ level as the most economical and practicable fertilizer instead of the standard dose $\mathrm{N}_{100} \mathrm{P}_{50} \mathrm{~kg} \mathrm{ha}^{-1}$ to get the desired level of Cry1Ac level for long lasting plant resistance $(<1.5)$. The revised dose of fertilizer may help farmers to avoid the cross-resistance development in contradiction of insect pests.
\end{abstract}

Keywords: fertilizer, Cry1Ac, Bt gene, transgenic cotton, ELISA.

\begin{abstract}
Resumo
A aplicação de diferentes fertilizantes para verificar a eficiência da expressão do gene Bt (Bacillus thuringiensis) em uma das principais culturas comercializadas (algodão) contra espécies de lepidópteros é uma grande preocupação. A expressão do nível de proteína Cry pode ser controlada pela melhoria dos níveis de nutrientes. Portanto, o mito da resposta da toxina Cry a diferentes combinações de fertilizantes NP foi explorado em três cultivares de algodão Bt. As combinações incluem três níveis de nitrogênio e três níveis de fertilizantes de fósforo. A análise de PCR (reação em cadeia da polimerase) específica para o gene (s) Immunostrips e Cry (s) foi usada para a presença do gene $B t$ que revelou a presença do gene Cry1Ac apenas. Além disso, o kit ELISA (ensaio de imunoabsorção enzimática) foi usado para quantificar a expressão da proteína Cry1Ac. Sob várias taxas de fertilizantes NP, o nível de proteína de toxina exibiu diferenças altamente significativas. A média do nível mais alto de toxina foi de 2,3740 e 2,1732 $\mu \mathrm{g} / \mathrm{g}$ sob o tratamento da combinação N150P75 $\mathrm{kg} \mathrm{ha}^{-1}$, enquanto a média do nível mais baixo de toxina foi de 0,9158 e $0,7641 \mu \mathrm{g}$ / g no nível de N50P25 kg ha-1 em 80 e 120 DAS (dias após a semeadura), respectivamente. Concluiu-se com a pesquisa que o uso de fertilizantes NP tem relação positiva com a expressão da toxina Cry1Ac no algodão Bt. Recomendamos o uso do nível de N150P50 kg ha-1 como o fertilizante mais econômico e praticável em vez da dose padrão N100P50 kg ha-1 para obter o nível desejado de nível de Cry1Ac para resistência de planta de longa duração (<1,5). A dose revisada de fertilizante pode ajudar os agricultores a evitar o desenvolvimento de resistência cruzada em contradição com as pragas de insetos.
\end{abstract}

Palavras-chave: fertilizante, $C r y 1 A c$, gene $B t$, algodão transgênico, ELISA.

*e-mail: shaukat_parc@yahoo.co.in

Received: December 10, 2020 - Accepted: February 26, 2021 


\section{Introduction}

Cotton (Gossypium hirsutum L.) is one of the foremost export cash crops and is considered as the backbone of Pakistan's economy (Tayyib et al., 2005). About $15 \%$ of the arable land in Pakistan is covered by this crop. Increased yield of this crop is very much important for developing country like Pakistan to boost up its economy. About $8 \%$ of the total GDP and 54\% of export is covered by cotton in Pakistan (Rehman, 2020). One of the fifteen economically vital pests, lepidopteron insects affects the yield of cotton to a great extent (Riaz Marral et al., 2020). In order to protect from these pests, $B t$ gene have been transformed in this crop (Chen et al., 2019). The Bt transgenic cotton is environment and human friendly as it reduces the use of toxic pesticides. Although it is not useful against all the cotton pests but it has resistance against few insect species (Mehmood et al., 2012).

To control the lepidopteron species, a sufficient Bt endotoxin expression is required in cotton. Environmental factors like drought, water logging, carbon dioxide availability and other nutrients deficiency can affect the $B t$ gene expression. The competence of transgene against lepidopteron species can be affected due to different expression levels of Cry1Ac protein leading to the development of cross resistance within insects (Bakhsh et al., 2011; Ali et al., 2012; Naik et al., 2018; Jamil et al., 2021). Close linkages have been found between toxin protein level and controlling efficacy (Adamczyk and Sumerford, 2001; Kranthi et al., 2005). The competence of Bt crops rely on the crystal gene's expression. Therefore, the level of Bt toxin is directly related with controlling efficiency of the pests (Rao 2005; Gutierrez et al., 2006).

The managing approaches especially the usage of balanced nutrients can be used to maintain and improve the Cry protein. Crop growth is greatly influenced by the major nutrients (NPK). Cry gene expression is greatly inclined at stage specific application of fertilizers. Dose optimization of different nutrients for the adequate expression of $\mathrm{Bt}$ gene in term of Bt toxin is important, whereas, decreased nutrients in soil causes the decrease in Bt gene expression (Zhou et al., 2000). About 85-90\% of land in Pakistan is devoid of phosphorous and 100\% as far as nitrogen is concerned (NFDC, 2001). Therefore, this study was designed to check the expression of Cry $1 \mathrm{Ac}$ toxin levels in Bt cotton under the treatments of several $\mathrm{N}-\mathrm{P}$ fertilizers combinations in glasshouse.

\section{Materials and Methods}

\subsection{Plant cultivation condition}

The experiment was performed at glasshouse in National Agricultural Research Centre (NARC), Islamabad-Pakistan

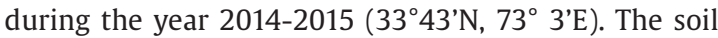
taken for this experiment was sandy and sampled from the fields of NARC and was desiccated, crushed and sieved through $2 \mathrm{~mm}$. The electrical conductivity, $\mathrm{pH}\left(\mathrm{v}_{\text {soil }}: \mathrm{v}_{\text {water }}=\right.$ $1: 5)$, organic matter, nitrate $\left(\mathrm{NO}_{3}-\mathrm{N}\right)$, Olsan-P and available K were 1.00 dS m¹, 8.19, $12 \mathrm{~g} / \mathrm{kg}, 7.82 \mathrm{mg} / \mathrm{kg}$ soil, $5.63 \mathrm{mg} /$ $\mathrm{kg}$ soil and $146 \mathrm{mg} / \mathrm{kg}$ soil, respectively.

\subsection{Layout of the study}

Soil (15 kg) was taken off in each pot of $38 \mathrm{~cm}$ diameter and $40 \mathrm{~cm}$ of height. Combinations of 3 doses of nitrogen fertilizer (50, 100 and $\left.150 \mathrm{~kg} \mathrm{ha}^{-1}\right)$ together with 3 doses of phosphorus fertilizers ( 25,50 and $\left.75 \mathrm{~kg} \mathrm{ha}^{-1}\right)$ were used in various fertilizers' treatments. Urea and di-ammonium phosphate were used as the bases of $\mathrm{N}$ and $\mathrm{P}$ fertilizers, respectively. Two equal doses were applied in case of nitrogen fertilizer; first dose was given at the time of sowing along with the full dose of P fertilizers, $2^{\text {nd }}$ half dose of $\mathrm{N}$ was given at 60 DAS. Fully factorial layout was used to test three Bt cotton genotypes and 10 treatments $\left(\mathrm{N}_{0} \mathrm{P}_{0}, \mathrm{~N}_{50} \mathrm{P}_{25}, \mathrm{~N}_{100} \mathrm{P}_{25}, \mathrm{~N}_{150} \mathrm{P}_{25}, \mathrm{~N}_{50} \mathrm{P}_{50}, \mathrm{~N}_{100} \mathrm{P}_{50}, \mathrm{~N}_{150} \mathrm{P}_{50}, \mathrm{~N}_{50} \mathrm{P}_{75}\right.$, $\mathrm{N}_{100} \mathrm{P}_{75}$ and $\mathrm{N}_{150} \mathrm{P}_{75} \mathrm{~kg} \mathrm{ha}^{-1}$ ) were replicated thrice. The three replicates were put up to calculate the toxin expression level in the third terminal leaves after 80 and 120 days of sowing. The seed of Bt cotton varieties namely FH-113, Bt121 and MNH-886 were acquired from National Institute for Genomics \& Advanced Biotechnology (NIGAB), NARC, Islamabad.

Ten seeds were sown in each pot and then the pots were thinned keeping only three seedlings.

\subsection{Immuno-strip analysis}

Presence of Cry toxins (Cry1Ac, Cry2Ab and Cry1F) was checked in each plant via specific immunostrips. $100 \mathrm{mg}$ of the fresh leaf tissue was excised from the plant and stored at $-80{ }^{\circ} \mathrm{C}$. Immunostrips having catalog no. of STX010300 and STX06800 were used for this study and samples preparation was done according to manufacturer's protocol (Agdia Inc. USA). The samples were then checked for the presence of Cry protein(s) (Figure 1). The prepared sample extracts were taken in eppendorf tubes and the strips were dipped carefully up to $0.5 \mathrm{~cm}$ to detect the Cry protein(s). The control line within 3-5 minutes indicates the validity of the test and results were taken as positive $(+)$ (Bt cotton) and negative (-) (non Bt cotton) on the origin of the line on the strip. The positive plants were considered for further analysis.

\subsection{PCR analysis}

CTAB protocol was used to extract the DNA from fresh leaves following Doyle and Doyle (1990) protocol. Event (Mon531) specific primer was used to confirm the gene presence via PCR. Reported primer by Yang et al. (2005) were commercially manufactured (Invitrogen, USA) for event specific (Mon531) and Stearoyl-ACP desaturase (Sad1) gene (internal control for cotton) are shown in Table 1 . The validity of PCR conditions was checked via $S A D 1$ gene primers. $20 \mu \mathrm{l}$ reaction volume was prepared with $50-60 \mu \mathrm{g} / \mu \mathrm{l}$ of template DNA for PCR reaction along with 10X PCR buffer, 10 picomole of forward and reverse primer, 25 milimolar of dNTPs mix, Taq DNA polymerase: $1 \mathrm{U}$ and nuclease free double distilled water. The PCR cycles were optimized as Initial denaturation: 1 cycle of $95^{\circ} \mathrm{C}$ for 5 minutes trailed by 35 cycle of second denaturation at $95^{\circ} \mathrm{C}$ for 30 seconds, primer annealing at $57^{\circ} \mathrm{C}$ for 40 seconds and extension at $72{ }^{\circ} \mathrm{C}$ followed by final extension at $72{ }^{\circ} \mathrm{C}$ for 10 minutes. The PCR products were resolved on $2 \%$ agarose gel in $1 \mathrm{X}$ TAE buffer at $95 \mathrm{~V}$ for $45 \mathrm{~min}$. 


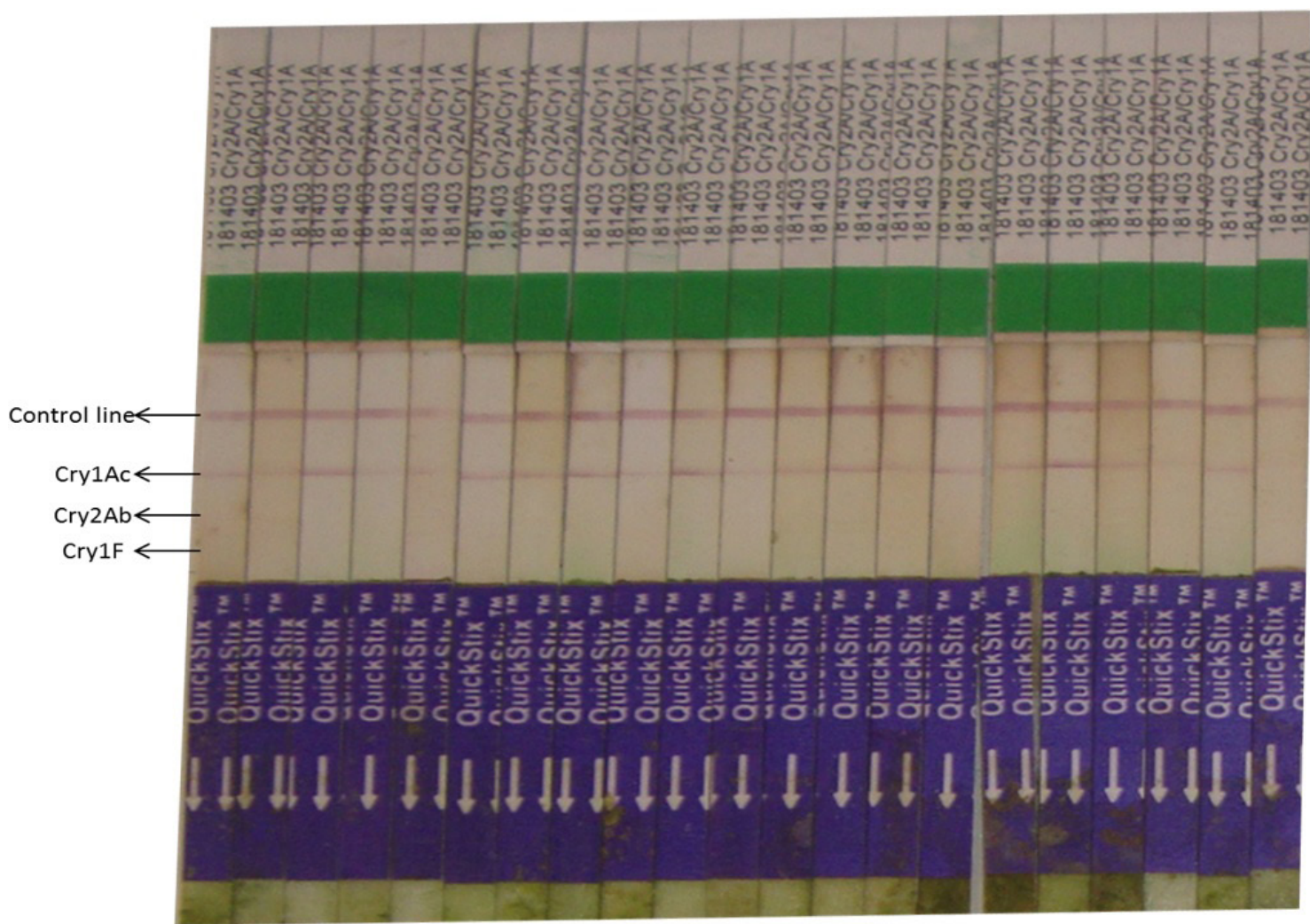

Figure 1. Detection of cry protein(s) via Immunostrip.

Table 1. Primer pairs used in PCR.

\begin{tabular}{|c|c|c|c|c|}
\hline Target & Primer & Sequences $\left(5^{\prime}-----3^{\prime}\right)$ & Specificity & Amplicon \\
\hline \multirow[t]{2}{*}{ Mon-531 } & Mon-531 F & AAGAGAAACCCCAATCATAAAA & \multirow[t]{2}{*}{ Genome/Cry1Ac } & \multirow[t]{2}{*}{$346 \mathrm{bp}$} \\
\hline & Mon-531R & GAGAATGCGGTAAAGATACGTC & & \\
\hline \multirow[t]{2}{*}{ Cotton endogenous gene } & Sad1 F & CCAAAGGAGGTGCCTGTTCA & \multirow{2}{*}{$\begin{array}{c}\text { Stearoyl-ACP } \\
\text { desaturase }\end{array}$} & \multirow[t]{2}{*}{$107 \mathrm{bp}$} \\
\hline & Sad1 R & TTGAGGTGAGTCAGAATGTTGTTC & & \\
\hline
\end{tabular}

PCR products were then pictured via a gel documentation system (Alpha Innotech, USA.). A 100 bp ladder was run in order to confirm the band size of Sad1 and Cry1Ac genes.

\subsection{Enzymes linked immunosorbent assay (ELISA)}

To quantify the expression of toxin level sandwich ELISA were performed at 80 and 120 DAS. For quantification of toxin, DNA samples were taken from the fully expanded leaf tissue of each Bt-cotton. The excised leaves were taken and suspended in the eppendorf tube in $1 \mathrm{X}$ extraction buffer (Envirologix Inc. USA) (500 $\mu 1)$ and ground manually. The prepared solution was subjected to centrifugation at $12000 \mathrm{rpm}$ for 5 minutes and supernatant was taken for the next procedure. ELISA was done via protocols available in the kit (Envirologix Inc. USA). The quantification of toxin protein was carried out by plotting the absorbance values of test samples and standard (purified toxin protein on ELISA plate) curve by simple regression $\left(\mathrm{R}^{2}\right)$ analysis (Crowther 2009).

\subsection{Statistical analysis}

Toxin level was interpreted via two-way ANOVA and their mean comparison were associated via LSD test. The data was analyzed via Statistix v. 8.1 (Analytical Software, 2005) package.

\section{Results}

\subsection{Immuno-strip analysis}

Bt gene (s) Cry1Ac, Cry2Ab and Cry $1 F$ expressions were evaluated using Immuno-Strip in transgenic Bt-cotton varieties. All evaluated explants were observed as Cry1Ac positive. Not a single plant revealed itself as a positive 
against other two genes: Cry $1 F$ (Wide Strike event) and Cry2Ab (Bollgard-II event) as exhibited in Table 2.

\subsection{PCR amplification}

At molecular level the confirmation of specific Cry1A gene is done via PCR. Results clearly showed the presence of Mon531 event in the tested transgenic cotton plants with the band size of 346. Internal control Stearoyl-ACPdesaturase; Sad1 amplifies in all plant $107 \mathrm{bp}$ along with Mon531 event (insecticidal gene) in all cotton plants. The negative control did not show any amplification as shown in Figure 2.

\subsection{Expression analysis of expressed toxin via ELISA}

PCR and immunostrip based confirmed plants were subjected to further screening via sandwich-ELISA to quantify the Cry1Ac protein with respect to the growth of plants (80 and 120 DAS) and numerous doses of NP fertilizers.

\subsection{Estimation of Cry1Ac toxin level in leaf sampled at 80 DAS}

Leaves were collected from tagged plants with specific NP dose at 80 DAS. Cry1Ac protein results for each plant (fresh leaf weight) after 80 DAS have been given in Table 3 . Plants grown in control conditions have Cry1Ac toxin expression ranging between $0.6912-0.8829 \mu \mathrm{g} / \mathrm{g}$, whereas, the level of expression was affected greatly on different fertilizer doses ranging from $0.8279-2.5038 \mu \mathrm{g} / \mathrm{g}$ in all understudied varieties. Variable doses of NP fertilizers showed significant differences of the Bt endo-toxins expression level among varieties via statistical analysis.

Table 2. Immunostrip analysis of all plant entries of three local Bt cotton varieties (MNH-886, Bt-121 and FH-113).

\begin{tabular}{cccc}
\hline Varieties & Cry1Ac & Cry2Ab & Cry1F \\
\hline MNH-886 & + & - & - \\
Bt-121 & + & - & - \\
FH-113 & + & - & - \\
\hline
\end{tabular}

$(+)=$ Bt gene presence, $(-)=B t$ gene absence
Treatment as well as varieties are significantly different to one another at $\mathrm{p} \leq 0.001$ and their interaction are significantly different with respect to varieties and treatment at $\mathrm{p} \leq 0.05$ (Table 3 ). The highest expression of Bt toxin i.e. $2.3740 \mu \mathrm{g} / \mathrm{g}$ was observed at fertilizers level $\mathrm{F}_{9}\left(\mathrm{~N}_{150} \mathrm{P}_{75} \mathrm{~kg} \mathrm{ha}^{-1}\right)$ trailed by $\mathrm{F}_{8}\left(\mathrm{~N}_{100} \mathrm{P}_{75} \mathrm{~kg} \mathrm{ha}^{-1}\right)(1.8236 \mu \mathrm{g} / \mathrm{g})$ and $\mathrm{F}_{6}\left(\mathrm{~N}_{150} \mathrm{P}_{50} \mathrm{~kg} \mathrm{ha}^{-1}\right)(1.7377 \mu \mathrm{g} / \mathrm{g})$ to the lowest mean toxin level $0.9158 \mu \mathrm{g} / \mathrm{g}$ was exhibit by $\mathrm{F}_{1}\left(\mathrm{~N}_{50} \mathrm{P}_{25} \mathrm{~kg} \mathrm{ha}^{-1}\right)$. The highest mean of toxin level of $1.5511 \mu \mathrm{g} / \mathrm{g}$ were shown by FH-113 trailed by Bt-121 and MNH-886 showing the expression of $1.4069 \mu \mathrm{g} / \mathrm{g}$ and $1.3122 \mu \mathrm{g} / \mathrm{g}$, respectively at 80 days after sowing (Table 3 ).

\subsection{Estimation of Cry1Ac toxin level in leaf sampled at 120 DAS}

Leaves from same tagged plants (taken at 80 DAS) were resampled to quantify the toxin level via ELISA. Significant decrease in the toxin level was observed as compared to 80 DAS as depicted in Table 3. At this stage of plant growth the toxin level ranged from $0.5810-0.7518 \mu \mathrm{g} / \mathrm{g}$ was observed in control while under different treatments of NP fertilizer levels the toxin expression ranged from $0.7068-2.3083 \mu \mathrm{g} / \mathrm{g}$ in all the under studied varieties. Like 80 days after sowing samples, treatments as well as varieties are significantly different to one another at $\mathrm{p} \leq$ 0.001 and their interaction are significantly different w.r.t varieties and treatment at $\mathrm{p} \leq 0.05$ at 120 DAS (Table 4). The highest expression of Bt toxin i.e. $2.1732 \mu \mathrm{g} / \mathrm{g}$ was observed at fertilizers level $\mathrm{F}_{9}\left(\mathrm{~N}_{150} \mathrm{P}_{75} \mathrm{~kg} \mathrm{ha}^{-1}\right)$ trailed by $\mathrm{F}_{8}\left(\mathrm{~N}_{100} \mathrm{P}_{75} \mathrm{~kg} \mathrm{ha}^{-1}\right)$ with expression level of $\left.1.6538 \mu \mathrm{g} / \mathrm{g}\right)$ and $\mathrm{F}_{6}\left(\mathrm{~N}_{150} \mathrm{P}_{50} \mathrm{~kg} \mathrm{ha}^{-1}\right)(1.5735 \mu \mathrm{g} / \mathrm{g})$ to the lowest mean toxin level $0.7641 \mu \mathrm{g} / \mathrm{g}$ was exhibit by $\mathrm{F}_{1}\left(\mathrm{~N}_{50} \mathrm{P}_{25} \mathrm{~kg} \mathrm{ha}^{-1}\right)$. The highest mean of toxin level $1.3769 \mu \mathrm{g} / \mathrm{g}$ were shown by FH-113 trailed by Bt-121 and MNH-886 showing the expression of $1.2645 \mu \mathrm{g} / \mathrm{g}$ and $1.1637 \mu \mathrm{g} / \mathrm{g}$, respectively at 120 days after sowing (Table 4 ).

\section{Discussion}

For the screening of Cry1Ac insecticidal gene from other two Cry genes that are Cry2Ab and Cry $1 F$ were confirmed via Immuno-strip test. PCR amplification results of all the under-test cotton varieties showed the band size

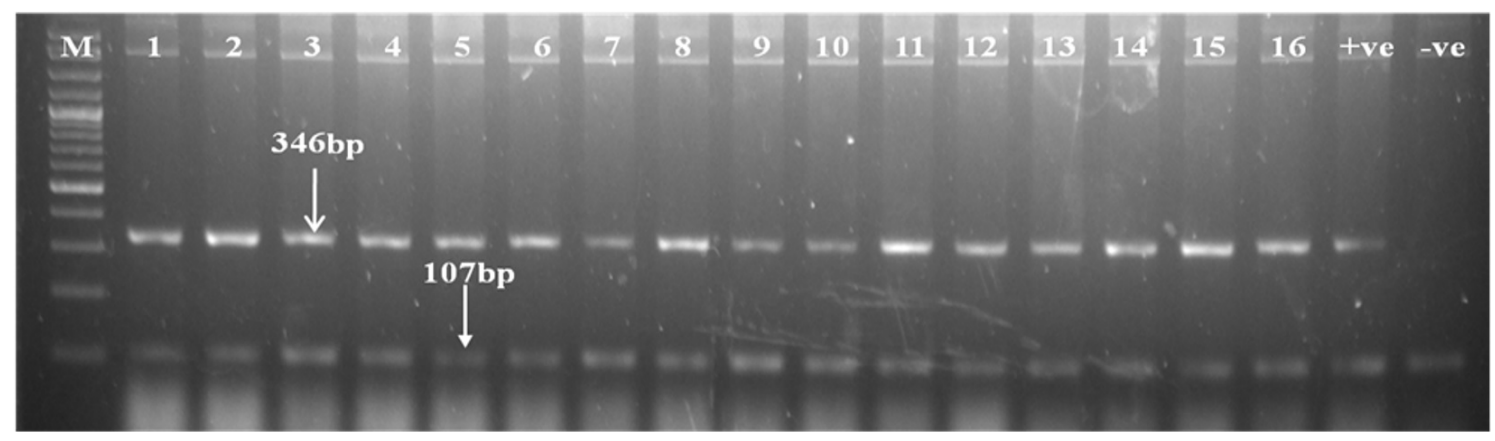

Figure 2. PCR Amplification of Mon531 (346 bp) event and Sad1 (107 bp) endogenous gene Lane (1-16), M= 100 bp DNA ladder, +ve (Bt cotton) and -ve control (Non Bt cotton). 
Table 3. Assessment of Cry1Ac toxin level $\left(\mu \mathrm{g} \mathrm{g}^{-1}\right)$ in 3 local Bt cotton varieties at 80 days after sowing (DAS) on numerous levels of N-P fertilizers.

\begin{tabular}{|c|c|c|c|c|}
\hline \multicolumn{5}{|c|}{ Variation in $C r y 1 A c$ toxin content $(\mu \mathrm{g} / \mathrm{g})$ at 80 DAS } \\
\hline Treatments & MNH-886 & Bt-121 & FH-113 & Mean \\
\hline $\mathrm{F}_{0}\left(\mathrm{~N}_{0} \mathrm{P}_{0}\right)$ & $0.6912^{\mathrm{s}}$ & $0.7535^{\mathrm{rs}}$ & $0.8829^{q}$ & $0.7758^{\mathrm{g}}$ \\
\hline $\mathrm{F}_{1}\left(\mathrm{~N}_{50} \mathrm{P}_{25}\right)$ & $0.8279^{\text {qr }}$ & $0.8934^{\mathrm{q}}$ & $1.0260^{\mathrm{p}}$ & $0.9158^{\mathrm{f}}$ \\
\hline $\mathrm{F}_{2}\left(\mathrm{~N}_{100} \mathrm{P}_{25}\right)$ & $1.0156^{p}$ & $1.1177^{\circ}$ & $1.2511^{\mathrm{mn}}$ & $1.1282^{\mathrm{e}}$ \\
\hline $\mathrm{F}_{3}\left(\mathrm{~N}_{150} \mathrm{P}_{25}\right)$ & $1.2918^{\mathrm{Im}}$ & $1.4073^{\mathrm{k}}$ & $1.5506^{\mathrm{ij}}$ & $1.4165^{\mathrm{d}}$ \\
\hline $\mathrm{F}_{4}\left(\mathrm{~N}_{50} \mathrm{P}_{50}\right)$ & $0.9869^{p}$ & $1.1522^{\circ}$ & $1.1806^{\mathrm{no}}$ & $1.1066^{\mathrm{e}}$ \\
\hline $\mathrm{F}_{5}\left(\mathrm{~N}_{100} \mathrm{P}_{50}\right)$ & $1.3039^{\mathrm{lm}}$ & $1.5059^{j}$ & $1.6136^{\mathrm{hi}}$ & $1.4745^{\mathrm{d}}$ \\
\hline $\mathrm{F}_{6}\left(\mathrm{~N}_{150} \mathrm{P}_{50}\right)$ & $1.6354^{\mathrm{gh}}$ & $1.7034^{\mathrm{fg}}$ & $1.8742^{\mathrm{e}}$ & $1.7377^{c}$ \\
\hline $\mathrm{F}_{7}\left(\mathrm{~N}_{50} \mathrm{P}_{75}\right)$ & $1.3547^{\mathrm{kl}}$ & $1.4182^{\mathrm{k}}$ & $1.6704^{\mathrm{gh}}$ & $1.4811^{\mathrm{d}}$ \\
\hline $\mathrm{F}_{8}\left(\mathrm{~N}_{100} \mathrm{P}_{75}\right)$ & $1.7545^{\mathrm{f}}$ & $1.7589^{\mathrm{f}}$ & $1.9575^{d}$ & $1.8236^{\mathrm{b}}$ \\
\hline $\mathrm{F}_{9}\left(\mathrm{~N}_{150} \mathrm{P}_{75}\right)$ & $2.2598^{c}$ & $2.3586^{\mathrm{b}}$ & $2.5038^{\mathrm{a}}$ & $2.3740^{\mathrm{a}}$ \\
\hline Mean & $1.3122^{c}$ & $1.4069^{b}$ & $1.5511^{\mathrm{a}}$ & \\
\hline
\end{tabular}

\begin{tabular}{cc}
\hline & Two-way ANOVA (F-values) \\
\hline Fertilizers (F) & $953.42^{* * *}$ \\
Varieties $(\mathrm{V})$ & $203.57^{* * *}$ \\
Interaction $(\mathrm{VxF})$ & $5.03^{*}$ \\
\hline Means sharing different letters within the same column are significantly different. F-values for Cry1Ac toxin expression followed by ${ }^{* * *},{ }^{* *}$ and ${ }^{*}$
\end{tabular}
within the column are significantly different at $(\mathrm{p}<0.001),(\mathrm{p}<0.01)$ and $(\mathrm{p}<0.05)$, respectively. Data reported as the mean of three replicates

Table 4. Assessment of Cry1Ac toxin level $\left(\mu_{\mathrm{g} \mathrm{g}} \mathrm{g}^{-1}\right)$ in 3 local Bt cotton varieties at 120 days after sowing (DAS) on numerous levels of N-P fertilizers.

\begin{tabular}{|c|c|c|c|c|}
\hline \multicolumn{5}{|c|}{ Variation in $C r y 1 A c$ toxin content $(\mu \mathrm{g} / \mathrm{g})$ at 120 DAS } \\
\hline Treatments & MNH-886 & Bt-121 & FH-113 & Mean \\
\hline $\mathrm{F}_{0}\left(\mathrm{~N}_{0} \mathrm{P}_{0}\right)$ & $0.6912^{\mathrm{s}}$ & $0.7535^{\text {rs }}$ & $0.8829^{\natural}$ & $0.7758^{g}$ \\
\hline $\mathrm{F}_{1}\left(\mathrm{~N}_{50} \mathrm{P}_{25}\right)$ & $0.8279^{q r}$ & $0.8934^{\mathrm{q}}$ & $1.0260^{\mathrm{p}}$ & $0.9158^{\mathrm{f}}$ \\
\hline $\mathrm{F}_{2}\left(\mathrm{~N}_{100} \mathrm{P}_{25}\right)$ & $1.0156^{p}$ & $1.1177^{\circ}$ & $1.2511^{\mathrm{mn}}$ & $1.1282^{\mathrm{e}}$ \\
\hline $\mathrm{F}_{3}\left(\mathrm{~N}_{150} \mathrm{P}_{25}\right)$ & $1.2918^{\mathrm{Im}}$ & $1.4073^{\mathrm{k}}$ & $1.5506^{\mathrm{ij}}$ & $1.4165^{\mathrm{d}}$ \\
\hline $\mathrm{F}_{4}\left(\mathrm{~N}_{50} \mathrm{P}_{50}\right)$ & $0.9869^{p}$ & $1.1522^{\circ}$ & $1.1806^{\text {no }}$ & $1.1066^{\mathrm{e}}$ \\
\hline $\mathrm{F}_{5}\left(\mathrm{~N}_{100} \mathrm{P}_{50}\right)$ & $1.3039^{\mathrm{lm}}$ & $1.5059^{\mathrm{j}}$ & $1.6136^{\mathrm{hi}}$ & $1.4745^{\mathrm{d}}$ \\
\hline $\mathrm{F}_{6}\left(\mathrm{~N}_{150} \mathrm{P}_{50}\right)$ & $1.6354^{\text {gh }}$ & $1.7034^{\mathrm{fg}}$ & $1.8742^{\mathrm{e}}$ & $1.7377^{c}$ \\
\hline $\mathrm{F}_{7}\left(\mathrm{~N}_{50} \mathrm{P}_{75}\right)$ & $1.3547^{\mathrm{kl}}$ & $1.4182^{\mathrm{k}}$ & $1.6704^{\mathrm{gh}}$ & $1.4811^{\mathrm{d}}$ \\
\hline $\mathrm{F}_{8}\left(\mathrm{~N}_{100} \mathrm{P}_{75}\right)$ & $1.7545^{\mathrm{f}}$ & $1.7589^{\mathrm{f}}$ & $1.9575^{\mathrm{d}}$ & $1.8236^{b}$ \\
\hline $\mathrm{F}_{9}\left(\mathrm{~N}_{150} \mathrm{P}_{75}\right)$ & $2.2598^{c}$ & $2.3586^{\mathrm{b}}$ & $2.5038^{a}$ & $2.3740^{\mathrm{a}}$ \\
\hline Mean & $1.1637^{c}$ & $1.2645^{\mathrm{b}}$ & $1.3769^{\mathrm{a}}$ & \\
\hline
\end{tabular}

Two-way ANOVA (F-values)

$\begin{array}{cc}\text { Fertilizers (F) } & 624.91^{* * *} \\ \text { Varieties }(\mathrm{V}) & 115.57^{* * *} \\ \text { Interaction }(\mathrm{VxF}) & 2.94^{*}\end{array}$

Means sharing different letters within the same column are significantly different. F-values for Cry 1 Ac toxin expression followed by ${ }^{* * *}$, ** and * within the column are significantly different at $(\mathrm{p}<0.001),(\mathrm{p}<0.01)$ and $(\mathrm{p}<0.05)$, respectively. Data reported as the mean of three replicates

observed was equal to $346 \mathrm{bp}$ (Mon531) event confirmed. Mon 531 event specified for Cry1Ac gene only as reported by Yang et al. (2005). Our results showed only one event confirmation among tested varieties. The results provide the evidence of Cry $1 \mathrm{Ac}$ insecticidal gene only in local cotton cultivars. Similar types of findings were reported 
by Iqbal et al. (2013) who just stated the presence of Cry1Ac gene via immunostrip test and confirmed the Mon5 531 event i.e. 346 bp band size in indigenous varieties.

The Cry1AC gene encoding the toxin protein is influenced by many factors that affect the expression of the Cry gene i.e. genetic background of the plant. In our study, expression of the $B t$ gene (Cry1Ac) showed to be affected by the genetic background of the plant varieties. FH-113 showed the highest expression of toxin protein while other two varieties Bt-121 and MNH-886 showed less expression of endotoxin among the tested varieties at 80 as well as 120 DAS. This depicted the linkage of $B t$ gene with the genetic history of the host. Similar types of findings were reported by Adamczyk and Sumerford (2001), two varieties that were DP458B / RR and NuCOTN 33B strongly expressed the toxin protein among 13 under test varieties. In another experiment they reported higher expression of $B t$ gene that shows the linkage of expression of $B t$ gene to the variety genetic history. Our finding was contrary to the Kranthi et al. (2005) who stated no linkage of genotype with the transgene expression.

On different doses of fertilizer treatments, the expression of toxin protein encoded by Bt gene was influenced among three cotton varieties. Results depicted that the increase in N-P fertilizer doses leads to the gradual increase in the expression of Cry1Ac toxin and vice versa. Our findings were similar to Zhou et al. (2000) who reported the significant change in the expression of toxin protein with the application of fertilizer. Beside this, Zhou et al. (2000) stated that the low fertilizer application leads to the declined expression of Bt cotton significantly. As phosphorous and nitrogen are two main components of the cell nuclei and have influence on synthesis of different essential compounds in the cells, leads to enhanced production of Cry protein, likewise, the increase in the nitrogen as well as phosphorus in our study showed increased level of toxin protein. Higher ratio of the toxin synthesizing mRNA and enzymes on increased accessibility of nitrogen $(\mathrm{N})$ ultimately increased production of Bt protein (Bruns and Abel, 2003).

Time based gene expression was obvious showing that 80 DAS plants' toxin level was greater than the 120 DAS plants samples. Adamczyk and Sumerford (2001) also reported similar types of results i.e. the higher expression of protein at early stages and gradually decreased towards plant maturity. At lateral growth phases of plants, the mRNA expression declines lead to the reduced level of $\mathrm{Bt}$ toxin level (Mahon et al., 2002). The expression of toxin level of Cry1Ac toxin declined because of methylation of 35 S promoter region as reported by Xia et al. (2005). Gene expression varies the expression pattern of Bt toxin. Variation in expression of inserted gene can occur due to the alteration in the nucleotide sequence, copy no. of transformed gene, type of promoter and location of gene incorporated into the DNA (Guo et al., 2001; Rao, 2005).

\section{Conclusion}

NP fertilizers have positive correlation with the $B t$ gene expression in Bt cotton as revealed by this study.
The fertilizer dosage was optimized (N-P fertilizers $\left(\mathrm{N}_{150} \mathrm{P}_{50} \mathrm{~kg} \mathrm{ha}^{-1}\right)$ for elevated level of Bt gene expression with respect to Bt toxin. In order to attain the long-lasting plant resistance $(>1.5)$ that will be economically feasible too, it is suggested to shift the dose of NP fertilizers from acclaimed dose $\left(\mathrm{N}_{100} \mathrm{P}_{50} \mathrm{~kg} \mathrm{ha}^{-1}\right)$ to $\left(\mathrm{N}_{150} \mathrm{P}_{50} \mathrm{~kg} \mathrm{ha}^{-1}\right)$ to have higher expression of Bt toxin. Nutrient management will be helpful for Bt cotton farming to attain the durable protection against the target insect pests. Cross resistance established in the further generations can be delayed via this dose.

\section{References}

ADAMCZYK, J.J. Jr. and SUMERFORD, D.V., 2001. Potential factors impacting season-long expression of Cry $1 \mathrm{Ac}$ in 13 commercial varieties of Bollgard cotton. Journal of Insect Science, vol. 1, no. 13, pp. 1-6. http://dx.doi.org/10.1673/031.001.1301. PMid:15455073.

ALI, S., SHAH, S.H., ALI, G.M., IQBAL, A., ULLAH, M.A. and ZAFAR, Y., 2012. Bt Cry toxin expression profile in selected Pakistani cotton genotypes. Current Science, vol. 102, pp. 1632-1636.

ANALYTICAL SOFTWARE, 2005. Statistix version 8.1: User"s manual. Tallahassee, Florida: Analytical Software

BAKHSH, A., SHAHZAD, K. and HUSNAIN, T., 2011. Variation in the spatio-temporal expression of insecticidal genes in cotton. Czech Journal of Genetics and Plant Breeding, vol. 47, no. 1, pp. 1-9. http://dx.doi.org/10.17221/131/2010-CJGPB.

BRUNS, H.A. and ABEL, C.A., 2003. Nitrogen fertility effects on Bt delta endotoxin and nitrogen concentration of maize during early stage. Agronomy Journal, vol. 95, no. 1, pp. 207-211. http:// dx.doi.org/10.2134/agronj2003.0207.

CHEN, Y., LI, Y., ZHOU, M.Y., CAI, Z., TAMBEL, L.I.M., ZHANG, X., CHEN, Y. and CHEN, D., 2019. Nitrogen deficit decreases seed Cry1Ac endotoxin expression in Bt transgenic cotton. Plant Physiology and Biochemistry, vol. 141, pp. 114-121. http://dx.doi. org/10.1016/j.plaphy.2019.05.017. PMid:31146093.

CROWTHER, J.R., 2009. Stages in ELISA. Methods in Molecular Biology (Clifton, N.J.), vol. 516, pp. 43-78. http://dx.doi.org/10.1007/9781-60327-254-4_3. PMid:19219585.

DOYLE, J.J. and DOYLE, J.L., 1990. Isolation of plant DNA from fresh tissue. Focus (San Francisco, Calif.), vol. 12, pp. 13-15.

GUO, W.Z., SUN, J., GUO, Y.F. and ZHANG, T.Z., 2001. Investigation of different dosage of inserted $B t$ genes and their insect-resistance in transgenic Bt cotton. Acta Genetica Sinica, vol. 28, no. 7, pp. 668-676. PMid:11480180.

GUTIERREZ, A.P., ADAMCZYK, J.J. Jr., PONSARD, S. and ELLIS, C.K., 2006. Physiologically based demographics of Bt cotton-pest interactions II. Temporal refuges, natural enemy interactions. Ecological Modelling, vol. 191, no. 3-4, pp. 360-382. http://dx.doi. org/10.1016/j.ecolmodel.2005.06.002.

IQBAL, A., ALI, S., ZIA, M.A., SHAHZAD, A., DIN, J., ASAD, M.A., ALI, G.M. and ZAFAR, Y., 2013. Comparative account of Bt gene expression in cotton under normal and salt affected soil. International Journal of Agriculture and Biology, vol. 15, pp. 1181-1186.

JAMIL, S., SHAHZAD, R., RAHMAN, S.U., IQBAL, M.Z., YASEEN, M., AHMAD, S. and FATIMA, R., 2021. The level of Cry1Ac endotoxin and its efficacy against $H$. armigera in Bt cotton at large scale in Pakistan. GM Crops and Food: Biotechnology in Agriculture and the Food Chain, vol. 12, no. 1, pp. 1-17. http://dx.doi.org/1 0.1080/21645698.2020.1799644. PMid:32762312.

KRANTHI, K.R., NAIDU, S., DHAWAD, C.S., TATWAWADI, A., MATE, K., PATIL, E., BHAROSE, A.A., BEHERE, G.T., WADASKAR, R.M. 
and KRANTHI, S., 2005. Temporal and intra-plant variability of Cry1Ac expression in Bt cotton and its influence on the survival of the cotton bollworm, Helicoverpa armigera (Hubner) (Noctuidae: lepidoptera). Current Science, vol. 89, pp. 291-297.

MAHON, R., FINNERGAN, J., OLSEN, K. and LAWRENCE, L., 2002. Environmental stress and the efficacy of Bt cotton. Aust. Cotton Grower, vol. 23, pp. 18-21.

MEHMOOD, Y., FAROOQI, Z., BAKHSH, K., ANJUM, M.B. and AHMAD, M., 2012. Impact of Bt cotton varieties on productivity: Evidence from district Vehari, Pakistan. Journal Agriculture \& Social Sciences, vol. 8, pp. 109-111.

NAIK, V.C., KUMBHARE, S., KRANTHI, S., SATIJA, U. and KRANTHI, K.R., 2018. Field-evolved resistance of pink bollworm, Pectinophora gossypiella (Saunders)(Lepidoptera: gelechiidae), to transgenic Bacillus thuringiensis (Bt) cotton expressing crystal 1Ac (Cry1Ac) and Cry2Ab in India. Pest Management Science, vol. 74, no. 11, pp. 2544-2554. http://dx.doi.org/10.1002/ps.5038. PMid:29697187.

NATIONAL FERTILIZER DEVELOPMENT CENTRE - NFDC, 2001. Balanced fertilization through phosphate promotion. Project terminal report. Islamabad, Pakistan: NFDC.

RAO, C.K., 2005 [viewed 23 March 2015]. Transgenic Bt technology: Expression of transgenes. [Online] Available from: http://www. monsanto.co.uk/news/ukshowlib.phtml?uid1/49304.

REHMAN, S.U., 2020 [viewed 12 February 2015]. Pakistan: Cotton and products annual (Report No. PK2020-0005, 1-8). Available from: https://www.fas.usda.gov/data/pakistan-cotton-andproducts-annual-4

RIAZ MARRAL, M.W., KHAN, M.B., AHMAD, F., FAROOQ S. and HUSSAIN, M., 2020. The influence of transgenic (Bt) and nontransgenic (non-Bt) cotton mulches on weed dynamics, soil properties and productivity of different winter crops. PLoS One, vol. 15, no. 9, pp. e0238716. http://dx.doi.org/10.1371/journal. pone.0238716. PMid:32886700.

TAYYIB, M., SOHAIL, A., SHAZIA, A., MURTAZA, F. and JAMIL, F.F., 2005. Efficacy of some new- chemistry insecticides for controlling the sucking insect pests and mites on cotton. Pakistan Entomologist, vol. 27, pp. 63-66.

XIA, L., XU, Q. and GUO, S., 2005. Bt insecticidal gene and its temporal expression in transgenic cotton plants. Zuo Wu Xue Bao, vol. 31, pp. 197-202.

YANG, L., PAN, A., ZHANG, K., YIN, C., QIAN, B., CHEN, J., HUANG, C. and ZHANG, D., 2005. Qualitative and quantitative PCR methods for event specific detection of genetically modified cotton Mon1445 and Mon531. Transgenic Research, vol. 14, no. 6, pp. 817-831. http://dx.doi.org/10.1007/s11248-005-0010-z. PMid:16315089.

ZHOU, D., WU, Z., WANG, X., NI, C., ZHENG, H. and XIA, J., 2000. Influence of fertilization and environmental temperature on the resistance of Bt transgenic cotton to cotton bollworm. J. Anhui Agri. Uni., vol. 27, pp. 352-357. 